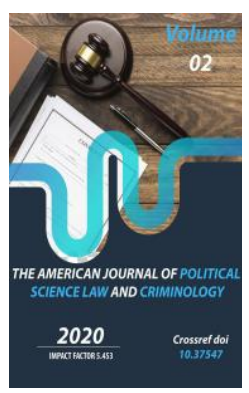

\title{
Legal Basis Of State Control In Agricultural Land Reclamation
}

\author{
Kurbonov Eldor Rashidovich \\ Chief Specialist Of The Supreme School Of Judges Under The Supreme Judicial Council Of The \\ Republic Of Uzbekistan, Independent Researcher Of Tashkent State University Of Law, \\ Uzbekistan
}

\section{ABSTRACT}

This article describes the role of state control in the field of land reclamation and importance of its legal provision, government functions in implementing control, forms of state control in the field of land reclamation, implementation legal expertise procedure in land reclamation, content and essence of land reclamation cadaster, as well as theoretical and practical analysis of legal basis for its maintenance, proposals for improving the legislation in this area.

\section{KEYWORDS}

Reclamation, land reclamation, land reclamation activities, state control, state control in the field of land reclamation, forms of state control in the field of land reclamation, land reclamation expertise, land reclamation cadaster.

\section{INTRODUCTION}

One of the most important tasks of public administration in the field of agricultural land reclamation is the implementation of state control.
State control over agricultural land reclamation ensures organization of land reclamation and rational use of reclaimed land. It is very important to establish regular state control 
over conduct of reclamation on agricultural lands. On the basis of state control, complete information on land reclamation facilities and irrigation networks and the condition of the land in general is collected.

State control in the field of land reclamation is carried out in two forms: state control over the implementation of land reclamation measures and state control over rational and effective use of reclaimed lands.

State control in the field of land reclamation includes monitoring of state bodies' activities in the field of land reclamation, improvement of land reclamation and compliance by land users with land reclamation requirements, as well as identification of causes and conditions of violation of land reclamation legislation and established requirements, taking into account also activities to eliminate or prevent these causes or conditions.

Experts acknowledge that the lack of systematic control is one of the main reasons for the deterioration of land reclamation and collector-drainage networks.[1] Problems and shortcomings in land reclamation in practice are still remaining directly related to organizational control issues.

The main task of state control over land use and protection is to ensure compliance with the requirements of land legislation by individuals, legal entities, public administration bodies and local public authorities.

Several forms of state control are used in the field of land reclamation and there are different scientific opinions on this issue.

While V.V. Petrov acknowledges existence of two main forms of state environmental control, namely environmental monitoring and environmental expertise [2], M.M. Brinchuk states that "Environmental control is carried out in the form of environmental standardization, environmental expertise, environmental licensing and environmental certification" [3].

Meanwhile, J.T. Kholmuminov recognizes such subinstitutes (elements) of state management of land use as land accounting, land use registration, land management, land control, planning, land allocation and withdrawal, crop rotation, land reclamation [4].

Indeed, control in the field of land reclamation also involves control whether the measures taken in accordance with established requirements meet the real order of land reclamation or not.

Forms of state control, such as land reclamation monitoring, expertise, maintenance of land reclamation cadaster have been widely used in improvement of reclamation of agricultural lands. The most important of these is monitoring in the field of land reclamation.

As to some scholars approach, land reclamation monitoring is linked to the observation of the environment in general. For example, according to V.V.Petrov, "Monitoring can be considered in a broader sense, that is, from the perspective of national development, not only as state environment monitoring but also as inspection over rule of law in this sphere and implementation of conservation measures" [5]. Meanwhile, J.T. Kholmuminov states that "monitoring includes not only observance over changes in environmental processes, pollution of natural objects and its consequences as impact on the environment, but also analysis of the received data and 
addressment of this information to concerned organizations and to the public" [6].

Goals and objectives of land monitoring, including land reclamation monitoring, are clearly defined in Article 14 of the Land Code of the Republic of Uzbekistan and in the Resolution of the Cabinet of Ministers "On Approval of Land Monitoring Instruction in the Republic of Uzbekistan" (No. 496 dated from December, 23, 2000). It is established that all lands of the Republic of Uzbekistan, regardless of their legal regime, purpose and nature of use, are the object of monitoring.

Consequently, we can state that monitoring in the field of land reclamation can be defined as a form of state control covering determination of land reclamation level, status of its evaluation, as well as analysis causes and conditions.

Monitoring over reclamation of irrigated lands in the Republic of Uzbekistan, as well as monitoring over hydrogeological condition of irrigated lands, quality of irrigation and collector-drainage waters is carried out by reclamation expeditions under regional Departments of Water Resources and Irrigation Systems of the Ministry of Water Resources of the Republic of Uzbekistan. Their main tasks are to study and monitor the level of salinity of the soil, groundwater, irrigation and collector water, as well as technical condition of inter-farm collector and drainage networks. They also have important tasks in monitoring land reclamation, such as development of recommendations on reclamation of lands, organization and conduct of observations, assessment and forecasting of land reclamation, prevention of negative processes and their elimination.
Therefore, monitoring of land reclamation includes specially organized systematic observations, identification, assessment and forecasting of changes in this sphere.

Regular analysis of the results of land reclamation monitoring and appropriate conclusions on the identified shortcomings, together with development of measures against them make up great practical and scientific importance. In this regard, today's problems and shortcomings in the organization of land reclamation should be noted. In particular, there are cases when there is no control and monitoring to ensure the validity of land reclamation activities.

Another important element of state control in the field of land reclamation is land reclamation expertise.

Feasibility studies, technical designs and development documents for construction and reconstruction of reclamation facilities and main collectors are subject to special expertise and examination at the Ministry of Construction.

Working (draft) projects for reconstruction and rehabilitation of all types of collectors and other reclamation facilities are examined by territorial examination departments of the Ministry of Construction and approved by the customer.

Working (draft) projects may be submitted to a specialized independent company (or expert) for additional expertise if necessary, the conclusion of which must be agreed with the Ministry of Construction.

Expertise in the field of land reclamation is designed to determine effectiveness and prospects of reclamation projects. 
Meanwhile, land reclamation cadaster in agriculture is also an important element of state control, ensuring collection and analyzing of complete information related to land reclamation.

Legal notion of land reclamation cadaster is given in the Resolution of the Cabinet of Ministers of the Republic of Uzbekistan "On measures to improve the formation of land reclamation programs and their implementation" (Resolution No. 361 dated from November 28, 2008). So, land reclamation cadaster is a data compendium of systemized quantitative indicators characterizing the metadata for reclamation condition of irrigated lands and technical condition of drainage systems. [7]

Current legislation does not provide for a separate cadaster of agricultural land reclamation. General information on agricultural lands is maintained by the Ministry of Agriculture of the Republic of Uzbekistan and data on reclamation and hydrotechnical constructions - by the Ministry of Water Resources of the Republic of Uzbekistan.

Taking into consideration direct allocation of state budget funds for land reclamation, legal regulation of cadaster is expedient in this regard. Thus, the Cabinet of Ministers of the Republic of Uzbekistan approved Instruction "On order of formation and keeping of Uniform System of State Cadasters" (Resolution dated from February, 16, 2005). This Instruction establishes formation of uniform system of state cadasters in order to ensure complex consideration and assessment of natural and economic potential of the Republic of Uzbekistan and its regions [8]. Currently, there is a uniform system of 20 state cadasters.
State control in the field of land reclamation is carried out through the forms of state control analyzed above.

Another aspect of state control in this regard is state control over land reclamation in reclaimed land. Establishment of state control is related to monitoring over land users' observance of their rights and obligations in the field of land reclamation. However, legal order of separate state control over reclaimed lands in our country is not fully created.

Appropriate measures are being taken by the competent authorities to address the identified violations. Monitoring of rational and efficient use of agricultural lands revealed violations of land legislation e.g. in the country, a total of 1,941 hectares of land in 4596 cases were arbitrarily occupied by land users and citizens, of which 337 hectares (17\%) were used inefficiently for building housing and other facilities [9].

The above mentioned analysis leads to conclusion that implementation of state control over agricultural land reclamation and improvement of legislation in this sphere serves for reduction of illegal activities in land usage.

Therefore, it is necessary to pay attention to the following:

Inclusion of "Land Reclamation Cadaster" into the existing uniform system of state cadasters. Through this, general information on the reclamation status of agricultural lands (condition, reclaimed lands, reclamation constructions etc.) may be formed;

creation of legal order of state control over reclaimed lands as an important component of land reclamation; 
Doi: https://doi.org/10.37547/tajpslc/Volume02Issue12-09

clear definition of tasks and responsibilities of local public authorities in the field of land reclamation.

\section{REFERENCES}

1. Yusupov A. Basic principles of improving reclamation of irrigated lands and prospects for increasing its potential // Ecological Bulletin. 2012. №11.

2. Petrov V.V. Ecology and law - M., 1991.

3. Brinchuk M.M. Ecological law. - M., 1990.

4. Kholmuminov J.T. Scientific and theoretical analysis of legal problems of prevention and elimination of environmental threats. Monography. Tashkent. TDYuU.2016.

5. Petrov V.V. Ecology and law - M., 1991.

6. Kholmuminov J.T. Environmental Law: Drawing Album: Textbook. - T.: Academy of the Ministry of Internal Affairs of the Republic of Uzbekistan, 2002.

7. Legislation Digest of the Republic of Uzbekistan, 2008, No. 49, Article 480. https://lex.uz

8. Legislation Digest of the Republic of Uzbekistan, 2005, No. 7, Article 59, No. 14, Article 103. https://lex.uz

9. National report on the condition of land resources of the Republic of Uzbekistan. Tashkent. 2020. 